\title{
Pengelolaan Tenaga Pendidik pada Lembaga Pendidikan Nonformal Bidang Keagamaan Islam
}

\author{
Syahrul $^{1}$, Yuniarni $^{2}$ \\ ${ }^{1}$ Fakultas Tarbiyah dan Ilmu Keguruan IAIN Kendari \\ Email: syahrul.stain@gmail.com \\ ${ }^{2}$ Fakultas Tarbiyah dan Ilmu Keguruan IAIN Kendari \\ Email: Yhuni019@gmail.com
}

\begin{abstract}
Abstrak
Artikel ini bertujuan menggambarkan pengelolaan tenaga pendidik pada lembaga pendidikan nonformal bidang keagamaan Islam, yang meliputi lima aspek kajian yaitu: 1) Perencanaan tenaga pendidik; 2) Pengorganisasian tenaga pendidik; 3) Pengarahan tenaga pendidik; 4) Pengembangan tenaga pendidik; dan 5) Pemberhentian tenaga pendidik. Penelitian ini dilakukan di TPQ Nurul Fitri Kendari melalui pendekatan kualitatif dengan metode naratif. Penelitian ini menemukan: pertama, perencanaan yang dilakukan melalui analisis faktor kebutuhan sumber daya pendidik kemudian menentukan kebutuhan sumber daya pendidik, perencanaan juga dilakukan pada rapat awal tahun di mana di dalamnya membahas hal-hal yang perlu dibenahi yaitu materi pembelajaran, sarana dan prasarana dan ujian santri. Kedua, Pengorganisasian dengan membagi setiap tenaga pendidik untuk bertanggungjawan terhadap level/kelas masing-masing sesuai dengan kualitas yang dimiliki dan memberikan tugas tambahan kepada guru untuk menduduki jabatan sebagai sekertaris dan bendahara. Ketiga, Pengarahan yang dilakukan oleh pimpinan mengacu pada dua aspek yaitu kedisiplinan dan tanggungjawab tenaga pendidik. Keempat, Pengembangan dilakukan melalui rotasi jabatan dan peembelajaran secara berkelompok yang melibatkan semua guruguru TPQ. Kelima, Pemberhentian tenaga pendidik di dasari oleh kemauan dari guru itu sendiri dengan faktor yang berbeda-beda.
\end{abstract}

Kata Kunci: Pengelolaan, Tenaga Pendidik, Pendidikan NonFormal, TPQ 


\title{
Management of Educators at Non-formal Islamic Education Institutions
}

\author{
Syahrul $^{1}$, Yuniarni $^{2}$ \\ ${ }^{1}$ Faculty of Tarbiyah and Teacher Training, IAIN Kendari \\ Email: syahrul.stain@gmail.com \\ ${ }^{2}$ Faculty of Tarbiyah and Teacher Training, IAIN Kendari \\ Email: Yhuni019@gmail.com
}

\begin{abstract}
This article aims to describe the management of teaching staff in non-formal educational institutions in the Islamic religious sector, which includes five aspects of study, namely: 1) Planning for educators; 2) Organizing of educators; 3) Direction of educators; 4) Development of educators; and 5) Termination of educators. This research was conducted at TPQ Nurul Fitri Kendari through a qualitative approach with a narrative method. This study found: first, planning is carried out through the analysis of the factor of teacher resource needs, then determining the need for educators, planning is also carried out at the initial meeting of the year where it discusses things that need to be addressed, namely learning materials, facilities and infrastructure and examinations. Students. Second, Organizing by dividing each teaching staff to be responsible for their respective levels / classes according to their quality and giving additional assignments to teachers to occupy positions as secretary and treasurer. Third, the direction carried out by the leadership refers to two aspects, namely the discipline and responsibility of the teaching staff. Fourth, development is carried out through job rotation and group learning that involves all TPQ teachers. Fifth, dismissal of teaching staff is based on the willingness of the teachers themselves with different factors.
\end{abstract}

Keywords: Management, Educators, NonFormal Education, TPQ 


\section{Pendahuluan}

Pengelolaan tenaga pendidik telah menjadi salah satu kajian dalam pengelolaan lembaga pendidikan, baik yang dikelola oleh Negara maupun masyarakat atau swasta (Karno \& Syahrul, 2020). Kebutuhan mengelola tenaga pendidik selanjutnya berkembang pada lembaga pendidikan nonformal seperti Taman Pendidikan Al-Qur'an atau TPQ, yang dilakukan sejalan dengan upaya peningkatan mutu (Aminullah, 2017). Jadi, pengelolaan tenaga pendidikan penting dilakukan karena terkait langsung dengan mutu.

Pengelolaan tenaga pendidik merupakan salah satu pembahasan penting dalam pengelolaan SDM lembaga pendidikan. Manajemen sumber daya manusia dalam organisasi memiliki fungsi yang amat penting dalam mencapai kinerja organisasi, dalam mencapai tujuan tersebut organisasi harus mampu mengelola dan mendayagunakan sumber daya manusianya agar mampu bekerja secara efektif dan efisien (Dewi, 2019). Setiap lembaga pendidikan baik formal maupun non formal, diperlukan berbagai unsur pendukung untuk tercapainya tujuan lembaga pendidikan, manajemen merupakan salah satu unsur penting yang keberadaannya dapat memberikan kontribusi luar biasa bagi terciptanya kompetensi pendidikan (Nurohmawati, 2017).

Salah satu sumber daya dalam manajemen adalah sumber daya manusia atau human resourch. Sumber daya manusia ini, perlu disadari oleh semua tingkatan manajemen termasuk juga manajemen pendidikan islam. Bagaimanapun majunya pendidikan saat ini, namun faktor manusia tetap memegang peranan penting bagi keberhasilan suatu organisasi. Bahkan dapat dikatakan bahwa manajemen itu pada hakikatnya adalah manajemen sumber daya manusia atau manajemen sumber daya manusia adalah identik dengan manajemen itu sendiri (Almasri M. N., 2016).

Yang menjadi pusat perhatian dalam sumber daya manusia adalah tenaga pendidik atau guru. Faktor guru apabila kita cermati merupakan faktor yang sangat penting dan tidak dapat diganti oleh apapun, karena guru sebagai subyek pendidik dan sebagai penentu keberhasilan dalam pendidikan itu sendiri (Harahap, 2019). Manajemen sumber daya pendidik atau guru sangat di butuhkan di semua lembaga pendidikan baik pendidikan formal maupun non formal, salah satunya lembaga pendidikan islam non formal yaitu Taman Pendidikan Al-Qur'an (TPQ). 
Peraturan pemerintah nomor 55 pasal 24 ayat 1 dan 2 tahun 2007 tentang pendidikan agama dan keagamaan menjelaskan bahwa: “(1) Pendidikan Al-Qur'an bertujuan meningkatkan kemampuan peserta didik membaca, menulis, memahami, dan mengamalkan kandungan Al-Qur'an. (2) Pendidikan AlQur'an terdiri dari Taman Kanak-kanak AlQur'an (TKQ), Taman Pendidikan Al-Qur'an (TPQ), Ta'limul Qur'an Lil Aulad (TQA), dan bentuk lain yang sejenis." (Kemenag, 2007).

Perkembangan BTQ di Indonesia sangatlah cepat, dari awal masuknya Islam ke Indonesia pembelajaran BTQ dimulai dari pondok pesantren, surau, rumahan, madin, dan yang paling baru adalah Taman Pendidikan Al-Qur'an (Kusuma, 2018). Mengajarkan Al-Qur'an merupakan salah satu dasar pendidikan Islam (Malik, 2013). Sebagai pokok agama, Al-Qur'an memegang peran yang sangat signifikan dalam pembentukan tingkahlaku manusia atau pembentukan akhlak yang mulia (Saichu, 2018).

Di lembaga nonformal ini para santri dididik menjadi peribadi yang baik, mencintai Al-Qur'an sebagai pedoman hidup, serta memiliki kemampuan lebih dalam hal baca tulis Al-Qur'an, sehingga dituntut para guru atau pengajar untuk memiliki kemampuan manajemen yang baik agar menghasilkan lulusan yang baik dan bisa bermanfaat di masyarakat (Syaharuddin, 2018). Tenaga pendidik merupakan unsur yang sangat mempengaruhi tercapainya tujuan pendidikan selain unsur murid dan fasilitas lainnya (M. Rusni Eka Putra, 2018). Kepala sekolah bertanggung jawab sukses atau tidaknya sekolah yang dipimpin, kepala sekolah merupakan faktor kunci, karena kepala sekolah memegang peranan penting dalam pengelolaan sekolah, begitu juga dengan pembinaan tenaga pendidik yang juga merupakan salah satu tugas dari kepala sekolah (M. Rusni Eka Putra, 2018). Begitu pula yang seharusnya di perhatikan oleh pimpinan Taman Pendidikan Al-Qur'an (TPQ) Nurul Fitri Kendari.

Manajemen tenaga pendidik khususnya di TPQ dilakukan melalui berbagai cara yang berbeda-beda, sebagaimana di TPQ AlHidayah Purwogondo Kalinyamatan Jepara pelaksanaan manajemen sumber daya pendidik dilakukan melalui 4 tahapan yaitu dimulai dari analisis kebutuhan dengan menggunakan alat analisis Benchmarking dan Brainstorming setelah itu penyusunan program perencanaan pengembangan dan pelaksanaan pengembangan sumber daya pendidik dan program pengembangan yang akan dilakukan berupa studi 
banding, pemberian tanggung jawab, pendampingan dan pembinaan dimana hal ini dilakukan langsung oleh Kepala TPQ (Munawaroh, 2014). Berbeda di TPQ Yasinat Jember manajemen sumber daya pendidik lebih memfokuskan pada perencanaan kebutuhan dan analisis sumber daya pendidik dimana melalui pola rekrutmen dan juga pengelolaan kompensasi dengan cara menganalisis dan mengevaluasi jabatan (Farikhin, 2018).

Adapun pada TPQ Nurul Fitri Kendari peneliti memfokuskan pada manajemen sumber daya pendidik melalui penerapan beberapa fungsi MSDM yaitu: perencanaan terkait dengan analisis kebutuhan dan perbaikan TPQ, pengorganisasian dengan membagi masingmasing guru untuk menangani murid per kelas/level, pengarahan dilakukan oleh pimpinan sehingga dapat melihat kinerja dan sejauh mana perhatian tenaga pendidik terhadap TPQ tersebut, rekrutmen diadakan untuk merekrut tenaga pendidik baru yang sesuai dengan kebutuhan, pengembangan dilakukan agar tenaga pendidik lebih meningkatkan kualitas dan kemampuan yang dimiliki, dan pemberhentian dilakukan jika terdapat tenaga pendiik yang tidak bisa lagi bekerja di tempat tersebut.

Manajemen sumber daya pendidik di Taman Pendidikan AlQur'an (TPQ) Nurul Fitri Kendari sangat penting dilakukan karena semua aspek kegiatan organisasi serta pembelajaran yang ada di TPQ Nurul Fitri Kendari berjalan atau tidaknya tergantung dari sumber daya manusia dalam hal ini tenaga pendidik yang ada di lembaga tersebut. Oleh karena itu perlu adanya suatu rancangan atau perencanaan yang dapat menjadikan TPQ Nurul Fitri Kendari lebih bermutu dan memiliki kualitas yang baik dalam hal akhlak dan pemahaman tentang Al-Qur'an.

Saat ini tenaga pendidik berjumlah 9 orang termasuk pimpinan, diantaranya 7 akhwat dan 2 Ikhwan dengan jumlah 75 siswa, persyaratan utama dalam pemilihan tenaga pendidik di TPQ ini mengenai menutup aurat dengan baik sesuai dengan syari'at Islam di samping itu juga masalah akhlak baik ketika berada dilingkungan TPQ maupun di luar TPQ, dan tentunya pengetahuan baca tulis AlQur'an yang baik dan benar, karena di TPQ ini bukan hanya lembaga yang sekedar mengajarkan Al-Qur'an kepada santri akan tetapi juga membimbing dan membina santri agar menjadi anak yang lebih mengedepankan akhlak, sehingga tenaga pendidik dapat menjadi contoh yang baik kepada santri. 
Sebagian tenaga pendidik di TPQ ini masih berstatus sebagai mahasiswa dan juga terdapat guru yang merangkap sebagai tenaga administrasi diantaranya sekertaris dan bendahara, sehingga hal ini membutuhkan pengelolaan yang baik agar TPQ dapat berjalan sesuai dengan yang diharapkan, tentunya hal ini tidak terlepas dari upaya pimpinan dalam memberikan motivasi, arahan, solusi dan pembagian kerja kepada masing-masing tenaga pendidik. Maka dari itu pengelolaan atau manajemen yang baik sangat dibutuhkan di TPQ Nurul Fitri Kendari agar lembaga ini dapat berjalan dengan baik terutama terhadap tenaga pendidik agar bekerja secara optimal sehingga dapat meningkatkan TPQ untuk kedepannya.

\section{Metode}

Artikel ini merupakan hasil penelitian pada TPQ Nurul Fitri Kendari, yang dilakukan secara kualitatif dengan metode naratif (Creswell, 2014). Karenanya, artikel ini akan memberikan deskripsi tentang praktik perencanaan sumber daya pendidik di TPQ Nurul Fitri. Pengumpulan data dilakukan melalui wawancara, pengamatan peran serta, dan telaah dokumen (Moleong, 2006). Data yang terkumpul dianalis secara bertahap mulai dari pengumpulan data, reduksi, data, penyajian data, hingga proses verifikasi dan penarikan kesimpulan (Miles, Huberman, \& Saldana, 2013). Pengujian keabsahan data dilakukan melalui perpanjangan pengamatan, peningkatan ketekunan, trianggulasi, dan member check (Sugiyono, 2013).

\section{Hasil Penelitian}

\section{A. Perencanaan Tenaga Pendidik}

\section{Pembuatan Sistem Informasi SDM}

Perencanaan sumber daya pendidik di TPQ Nurul Fitri ketika TPQ kekurangan tenaga pendidik karena akan berpengaruh dalam proses pembelajaran dengan banyaknya jumlah santri yang akan di ajar. Pimpinan TPQ mengatakan bahwa: "Ketika TPQ kekurangan tenaga pendidik maka kami berupaya agar cepat dapat guru karena itu akan berpengaruh dalam proses pembelajaran karena banyaknya jumlah santri yang akan di ajar, jadi kalau tidak ada penambahan guru maka guru yang tersisa akan kewalahan dalam mengajar". Hal tersebut terjadi karena adanya tenaga pendidik yang berhenti dan mempunyai kegiatan kampus yang wajib dilakukan seperti PPL/Magang dan juga 
KKN sehingga untuk sementara waktu tidak dapat mengajar di TPQ, sehingga dengan hal ini pihak TPQ akan kekurangan tenaga pendidik. Hal ini ditegaskan pimpinan TPQ bahwa: "Melihat kondisi yang ada banyak guru-guru TPQ yang masih sedang kuliah sehingga mau tidak mau terkadang ada kegiatan kampus yang wajib dilakukan dan itu waktunya lama seperti PPL/Magang dan juga KKN sehingga para guru untuk sementara waktu tidak bisa mengajar di TPQ.

\section{Penetapan Tujuan dan Kebijakan SDM}

Maka pihak TPQ melakukan rapat terlebih dahulu untuk mengusulkan perencanaan tenaga pendidik dengan melihat jumlah tenaga pendidik yang dibutuhkan pada saat itu sesuai dengan jumlah santri dan tenaga pendidik yang tersisa. Adapun kriteria tenaga pendidik yang dibutuhkan yaitu memahami baca tulis Al-Qur'an dan pemahaman tajwid yang baik, juga akhlak, memiliki kendaraan, dimana pada level 1 tenaga pendidik yang dibutuhkan yaitu yang mampu baca tulis Al-Qur'an dengan baik dan yang menyayangi anak-anak sehingga bisa berinteraksi dengan anak usia 8 tahun ke bawah, pada level 2 tenaga pendidik yang dibutuhkan yaitu selain mampu baca tulis AlQur'an, sudah menguasai ilmu tajwid, dan level 3 tenaga pendidik yang dibutuhkan yaitu sudah menguasai ilmu tajwid, bacaan Al-Qur'annya baik juga memiliki hafalan Al-Qur'an minimal 1 Juz. Hal ini sebagaimana diungkapkan oleh Pimpinan TPQ yaitu: "Kriteria yang kami harapkan bisa dipenuhi oleh tenaga pendidik di level $1 \mathrm{kami}$ berharap tenaga pendidik yang mampu membaca Al-Qur'an dengan baik dan yang mampu mengatasi karakter anak-anak yang masih sangat butuh ekstra perhatian seperti itu, untuk level 2 yaitu tenaga pendidik yang mampu membaca Al-Qur'an juga tajwid dan mengajarkan kepada santrinya akhlak yang baik karena mereka sudah paham dan sudah bisa dibimbing dengan baik, dan untuk level 3 tenaga pendidik yang dibutuhkan tentunya bacaan Al-Qur'annya bagus, ilmu tajwidnya, saya berharap kalau mereka juga memiliki hafalan karena santri yang di ajar hafalan surahnya Alhamdulillah sudah banyak."

3. Rekruitmen Tenaga Pendidik 
Rekrutmen sumber daya pendidik dilakukan dalam rangka mendapatkan tenaga pendidik yang sesuai dengan yang dibutuhkan di TPQ Nurul Fitri Kendari, pengadaaan rekrutmen hanya terjadi jika pihak TPQ kekurangan tenaga pengajar baik karena adanya tenaga pendidik yang keluar dan juga karena adanya tenaga pendidik yang harus digantikan untuk sementara waktu, untuk tahun 2020 belum diadakan tahap rekrutmen karena pihak TPQ sudah mempunyai tenaga pendidik yang cukup.

Proses rekrutmen yang dilakukan di TPQ Nurul Fitri berbeda dengan proses rekrutmen pada umumnya dimana dilakukan melalui pemberian tugas kepada masing-masing guru untuk mencari teman atau kerabat yang betul-betul mencapai kriteria yang telah ditetapkan di TPQ sesuai dengan jumlah tenaga pendidik yang dibutuhkan, setelah itu pihak pimpinan melakukan pendekatan secara personal kepada calon pengajar sesuai dengan peraturan-peraturan yang harus di penuhi yaitu terkait dengan penampilan, pemahaman dan pengamalan dalam arti sudah terdidik terlebih dahulu sehingga dapat mendidik para santrinya. Hal ini dibenarkan oleh Pimpinan TPQ Nurul Fitri Kendari yang menuturkan bahwa: "Perekrutan tenaga pendidik di TPQ yaitu melalui pendekatan secara personal kepada pihak calon pengajar dimana kami pihak tpq telah memilki pertauranperaturan yang harus dipenuhi oleh para guru baik mulai dari penampilan, pemahaman dan pengamalan sehingga tiga aspek itu yang menjadi tolak ukur kami dalam merekrut calon-calon guru, sehingga guru-guru yang ikut gabung dalam tpq adalah yang betul-betul guru yang sudah tersaring secara kemampuan dan pengalaman serta pengamalan dalam arti kata guru yang insyaAllah sudah terdidik terlebih dahulu sehingga mereka dapat mendidik para santrinya.

\section{B. Pengorganisasian Tenaga Pendidik}

Pengorganisasian sumber daya pendidik di TPQ Nurul Fitri ditetapkan melalui rapat pada awal bulan karena setiap tahunnya terdapat guru yang tidak mengajar lagi maka dilakukan pembagian tugas lagi dan juga danya penambahan tenaga pendidik baru, dimana pada pembagian tugas tersebut berdasarkan tingkat kemampuan guru dalam arti bukan hanya mampu dalam memahami baca tulis al-qur'an 
tetapi mampu memahami psikologis para santri, terutama di level 1 guru yang diamanahkan lebih banyak di banding level lainnya karena selain jumlah santri yang banyak juga santri yang berada di level 1 memiliki usia 8 tahun ke bawah oleh karena itu senantiasa memilih guru yang mampu mengatasi karakter anak-anak yang masih sangat membutuhkan ekstra perhatian.

Di level 2 dimana merupakan tingkat sedang yaitu santri yang berumur 9 sampai 12 tahun dimana sudah tidak terlalu sulit lagi dalam mengarahkan dan mengawasi santri dan pada level 3 yang merupakan level mandiri dimana berusia 13 tahun ke atas dan merupakan satri yang sudah mencapai tingkat bacaan Al-qur'an dimana guru yang bertanggung jawab untuk bisa menyiapkan para santrinya dalam menghadapi ujian santri.

Pembagian tugas berdasarkan tingkat kemampuan guru dalam arti kata bukan hanya mampu dalam memahami baca tulis al-qur'an tetapi mampu dan memahami psikologis para santri terutama dilevel 1 kami memilih betul-betul guru yang banyak untuk di tempatkan dilevel 1 di mana santrinya masih cenderung kanak-kanak yaitu usia kiasaran 5 tahun sampai 8 tahun oleh karena itu senantiasa betul-betul memilih guru mana yang mampu mengatasi karakter nak-anak yang masih sangat butuh ekstra perhatian seperti itu, kemudian level 2 dan 3 dimana tingkat sedang sehingga gurunya tidak terlalu sulit lagi untuk mengawasi dan level 3 yang merupakan level mandiri dimana level tersebut adalah guru yang bertanggung jawab untuk bisa menyiapkan para santrinya untuk menghadapi ujian santri, jadi setiap level guru mempunyai tanggung jawab masing-masing yang memang cukup berat.

Selain itu yang ditugaskan menjadi bendahara dan sekertaris di TPQ Nurul Fitri juga merupakan tenaga pengajar di TPQ ini, jadi terdapat beberapa guru yang mempunyai dua tanggung jawab. Dengan adanya dua tanggung jawab tersebut tidak menjadi penghalang bagi guru yang bersangkutan untuk tetap melakukan proses pembelajaran dengan baik.

\section{Pengarahan Tenaga Pendidik}

Penerapan fungsi selanjutnya yaitu fungsi pengarahan yang dimana dilakukan apabila ada hal yang harus diperbaiki, apabila hal tersebut cukup ringan maka pimpinan melakukan peneguran secara 
personal akan tetapi jika masalah tersebut sudah menjadi besar maka akan dibahas pada forum rapat bulanan.

Hal ini sesuai dengan wawancara Pimpinan TPQ Ibu Etika Fitriani yaitu:"Sistem pengarahan yang dilakukan itu apabila ada hal yang mungkin harus diperbaiki maka kamiakan adakan rapat apabila hal tersebut cukup ringan maka saya akan mengadakan peneguran secara personal akan tetapi masalah itu sudah menjadi besar maka kami akan membahas di forum rapat bulanan seperti itu." Hal senada juga disampaikan oleh guru TPQ yaitu: "Dalam setiap kegiatan pimpinan selalu memberikan arahan jika ada hal yang harus disampaikan beliau langsung menyampaikan kepada guru-guru".

lain:

Bentuk engarahan yang diberikan di TPQ Nurul Fitri antara

\section{Kedisiplinan}

Pengarahan kedisiplinan berupa ketepatan waktu datang dan pulang ke TPQ, terutama guru yang piket pada hari itu pimpinan selalu mengarahkan agar waktunya di atur dengan baik. Sebagaimana yang diungkapkan oleh Pimpinan TPQ Ibu Etika Fitriani yaitu: "Pengarahan mengenai kedisiplinan waktu, saya selalu berupaya untuk terus mengarahkan para guru agar waktunya bisa diatur lebih baik lagi, hal ini saya sering sampaikan ketika rapat maupun di grup Whatsapp". Hal senada juga diungkapkan oleh guru TPQ Bunga Fatimah, yaitu: "Saat kegiatan TPQ dimulai , mulai dari proses pembersihan hingga muroja'ah di awal pimpinan mengecek santri dan kehadiran guru piket tepat waktu dan mengingatkan guru-guru yang piket sebelum jam TPQ tiba dan terkadang pimpinan juga selalu memberikan wejangan-wejangan sebelum proses pembelajaran dimulai."

2. Tanggung jawab

Pengarahan yang kedua yaitu tanggung jawab berupa tanggung jawab level yang dipegang dan juga hal lain yang telah diberikan. Sebagaimana hal ini diungkapkan oleh Pimpinan TPQ Ibu Etika fitriani yaitu: "Alhamdulillah dengan adanya pengarahan yang sering kami lakukan terutama pada kegiatan rapat guru-guru semua bertanggung jawab terhadap apa yang diamanahkan adapun mereka tidak 
melaksanakan kewajibannya atau apa yang telah diamanahkan itu tejadi karena ada uzur yang syar'i."

Mengenai tanggung jawab setiap guru berupaya untuk melakasanakan dengan baik dimana tidak terlepas dari peran seorang pimpinan yang selalu memberikan arahan kepada tenaga pendidik. Hal ini diungkapkan oleh guruguru TPQ yaitu: "Pelaksanaan tanggung jawab yang diberikan diupayakan untuk selalu dilakukan dengan sebaik mungkin oleh setiap guru karena para guru di TPQ sudah berstatus sebagai mahasiswa dan juga sebagian sudah sarajana maka kita senantiasa mengatur waktu untuk TPQ di tengah kesibukan masing-masing demi berlangsungnya proses pembelajaran dengan baik."

Dalam melaksanakan tanggung jawabnya guru melakukan dengan baik dengan penuh tanggungjawab." Tanggung jawab tersebut sangat diperhatikan oleh masingmasing tenaga pendidik dan selalu memperhatikan setiap arahan yang diberikan Pimpinan, bahkan ketika adanya pandemi Covid 19 ini pihak TPQ yakni Pimpinan bekerjasama dengan tenaga pendidik untuk tetap berupaya agar santri tidak libur mengajinya jadi pimpinan mengarahkan kepada tenaga pendidik untuk tetap mengontrol bacaan santri melalui Whatsapp dengan melibatkan peran orang tua jadi dimana para orang tua melaporkan bacaan anaknya sesuai dengan jadwal TPQ dalam bentuk video, voice note dan foto.

Dalam program ini para tenaga pendidik selalu semangat mengingatkan, memberikan arahan dan memperbaiki bacaan para santri walaupun tidak semua orang tua mengindahkan himbauan ini akan tetapi di tengah keterbatasan para guru tetap bekerja sama untuk setiap harinya mengingatkan orang tua untuk memberikan laporan baik di grup maupun melalu jalur pribadi.

\section{Pengembangan Tenaga Pendidik}

Pengembangan sumber daya pendidik yang dilakukan di TPQ Nurul Fitri karena keuangan yang dimiliki masih sangat minim maka pihak TPQ belum mampu melakukan pelatihan atau pendidikan kepada tenaga pendidiknya, akan tetapi karena keterbatasan tersebut 
pihak TPQ tetap berupaya agar tenaga pendidik dapat meningkatkan kualitasnya yaitu melalui rotasi jabatan dimana setiap pengadaan rapat di awal tahun sering dilakukannya pemindahan tanggung jawab atau kelas yang dipegang dalam rangka tenaga pendidik memperoleh pengetahuan yang lebih luas dan juga untuk melihat setiap tenaga pendidik cocoknya di tempatkan dimana. Selain itu selama 10 menit setelah proses pembelajaran telah dilakukan guru-guru TPQ Nurul Fitri mengadakan pembelajaran tahsin untuk memperbaiki kesalahankesalahan dalam pelafalan huruf maupun tajwid yang didengarkan dan dikoreksi secara bersama oleh guru-guru TPQ. Dan juga jika terdapat guru yang mempunyai kendala sehingga tidak hadir maka guru yang hadir di hari tersebut akan langsung dibagi agar tidak ada kelas yang terkendala dalam proses pembelajaran hal ini dilakukan untuk lebih membangun kerja sama antar tenaga pendidik dan juga mengajarkan bahwa tanggung jawabnya bukan hanya berfokus pada kelas yang dipegang akan tetapi tanggung jawabnya adalah semua santri yang ada di TPQ.

Hal ini dibenarkan oleh Pimpinan TPQ Nurul Fitri Kendari yaitu: Dengan keterbatasan yang kami miliki, kami tetap berupaya agar TPQ dapat berjalan dengan baik terutama guru-gurunya maka upaya yang kami lakukan setiap tahunnya pada saaat rapat dilakukan evaluasi dan pemindahan penanggung jawab kelas jika memang diperlukan selain itu untuk lebih memperbaiki bacaan santri maka guru-gurunya juga harus tetap belajar jadi setiap hari sebelum pulang kami berkumpul kurang lebih 10 menit untuk sama-sama mengoreksi bacaan jika terdapat kesalahan.

\section{E. Pemberhentian Tenaga Pendidik}

Pemberhentian sumber daya pendidik dari dulu sampai sekarang pihak TPQ tidak pernah melakukan pemberhentian, karena pihak TPQ sudah menganggap bahwa tenaga pendidik yang berada dilingkungan TPQ adalah orang-orang yang sudah terdidik terlebih dahulu dimana selain mempunyai pengetahuan tentang Al-Qur'an juga mempunyai akhlak yang baik. Melainkan pemberhentian terjadi karena kemauan dari tenaga pendidik tersebut karena berbagai faktor diantaranya: tempat tinggalnya jauh dari TPQ, sudah menikah, dan lain sebagainya. Pada dasarnya pihak TPQ tidak menginginkan adanya tenaga pendidik yang berhenti karena untuk mencari penggantinya bukan lah hal yang mudah. 


\section{Pembahasan}

\section{A. Perencanaan Tenaga Pendidik}

Perencanaan sumber daya pendidik yang dilakukan TPQ Nurul Fitri Kendari melalui analisis kebutuhan tenaga pendidik yaitu ketika TPQ kekurangan tenaga pendidik dengan melihat kriteria dan jumlah tenaga pendidik yang dibutuhkan di TPQ. Hal ini sesuai dengan pemaparan Astuti dalam penelitian (Akilah, 2017), perencanaan sumber daya manusia merupakan kegiatan menaksir/menghitung kebutuhan sumber daya manusia dan selanjutnya merumuskan upaya-upaya yang perlu dilakukan untuk memenuhi upaya-upaya tersebut. Upaya-upaya tersebut mencakup kegiatan menyusun dan melaksanakan rencana agar jumlah dan kualifikasi personel yang diperlukan tersedia pada saat dan posisi yang tepat sesuai dengan tuntutannya.

Sebagaimana dalam penelitian Nani I. Rajaloa dan Rustam Hasim, perencanaan yang dilakukan oleh Dinas Pendidikan Nasional Kota Ternate dengan melakukan koordinasi dengan Kabit Ketenagaan Dinas Pendidikan Nasional Kota Ternate, sehingga diharapkan tidak akan terjadi kekurangan bagi guru kelas sehingga terpenuhi jumlah guru kelas dengan jumlah rombel belajar melalui perencanaan kebutuhan dengan analisis faktor eksternal dan internal seperti kebutuhan guru, analisis sumber daya yang tersedia saat ini mencakup dua hal yaitu deskripsi kerja dan spesifikasi kerja (Rajaloa \& Hasim, 2016). Hal tersebut menjelaskan bahwa perencanaan tenaga pendidik dengan melakukan analisis pekerjaan kemudian melihat jumlah tenaga pendidik yang dibutuhkan dengan tingkat kemampuan atau keterampilan tertentu.

Perencanaan sumber daya manusia merupakan fungsi utama yang harus dilaksanakan dalam organisasi, guna menjamin tersedianya tenaga kerja yang tepat untuk menduduki berbagai posisi, jabatan dan pekerjaan yang tepat pada waktu yang tepat (Sutrisno E. , 2009). Menurut Mondy dan Noe mendefinisikan perencanaan SDM sebagai proses secara sistematis mengkaji keadaan SDM untuk memastikan bahwa jumlah dan kualitas dengan keterampilan yang tepat, akan tersedia pada saat mereka dibutuhkan (Suwatno, 2011). Perencanaan adalah merencanakan tenaga kerja secara efektif serta efisien agar sesuai dengan kebutuhan perusahaan dalam membantu terwujudnya tujuan (Hasibuan M. S., 2005). Perencanaan juga merupakan tindakan memilih dan menetapkan segala program dan sumber daya yang 
dimiliki oleh suatu organisasi untuk mencapai tujuannya di masa depan secara optimal (Hadijaya, 2012).

Perencanaan sumber daya manusia yang tepat membutuhkan langkah-langkah tertentu berkaitan dengan aktivitas sumber daya manusia menurut organisasi modern. Langkah-langkah tersebut meliputi: 1) pengumpulan dan analisis data untuk mermalkan permintaan maupun peresediaan sumber daya manusia yang diespektasikan bagi perencanaan masa depan; 2) mengembangkan tujuan perencanaan sumber daya manusia; 3) merancang dan mengimplementasikan program-program yang dapat memudahkan organisasi untuk pencapaian tujuan perencanaan sumber daya manusia; 4) mengawasi dan mengevaluasi program-program yang berjalan (Sutrisno, 2009).

Terdapat empat kegiatan dalam system perencanaan SDM adalah: pertama, inventarisasi persedian SDM, pencatatan atau pendataan jumlah SDM yang ada dala melaksanakan tugas di suatu organisasi atau pencatatan atau pengumpulan data tentang kegiatan, hasil yang dicapai, pendapatan umum, sekarang atau yang sedang terjadi. Kedua, peramalan SDM, berguna untuk memprediksi permintaan karyawan dimasa datang. Metode permalan ketersediaan/penawaran karyawan dari sumber eksternal terdiri atas: perencanaan rekrutmen dan seleksi (dari dalam organisasi, dan pasar karyawan (dari luar organisasi). Ketiga, penyusunan rencana SDM, dapat diartikan sebagai suatu proses menentukan kebutuhan akan karyawan berdasarkan peramalan pengembangan, pengimplementasian, dan pengendalian kebutuhan tersebut yang berintegrasi dengan perencanaan organisasi agar tercipta jumlah karyawan, penempatan karyawan (Arifin, 2017).

Rekrutmen adalah proses seleksi dan penarikan, penempatan untuk mendapatkan karyawan yang sesuai dengan kebutuhan perusahaan. Proses rekrutmen yang menghasilkan karyawan yang sesuai akan membantu terwujudnya tujuan perusahaan (Hasibuan M. S., 2005). Rekrutmen adalah suatu proses mencari, menemukan, dan menarik para pelamar atau tenaga kerja baru untuk memenuhi kebutuhan SDM untuk dipekerjakan dalam suatu organisasi. Dalam hal ini perekrutan dna penyeleksian karywan, manajer sumber daya manusia harus mencocokkan keahlian pelamar dengan kebutuhan (Almasri, 2016). 
Ada beberapa sumber rekrutmen, yaitu:

1. Pelamar langsung artinya para pencari pekerjaan datang sendiri ke suatu organisasi untuk melamar, ada kalanya tanpa mengetahui apakah di organisasi yang bersangkutan ada atau tidak ada lowongan yang sesuai dengan pengetahuan, keterampilan atau pengalaman pelamar yang bersangkutan. Dimana terdiri dari dua yaitu: 1) lamaran tertulis dimana para pelamar mengajukan lamaran terlulis yang melengkapi surat lamarannya dengan berbagai bahan tertulis mengenai dirinya. 2) lamaran berdasarkan informasi orang dalam, sumber rekrutmen ini layak dipertimbangkan karena beberapa alasan, yaitu: a) para pencari karyawan baru memperoleh bantuan dari pihak dalam organisasi untuk mencari karyawan baru sehingga biaya yang harus dipikul oleh organisasi menjadi lebih ringan, b) para karyawan yang menginformasikan lowongan itu kepada teman atau kenalannya agar berusaha hanya yang paling memenuhi syaratlah yang melamar, c) para pelamar sudah memiliki bahan informasi tentang organisasi yang akan dimasukinya sehingga lebih mudah melakukan berbagai penyesuaian yang diperlukan jika ternyata diterima, d) pengalaman banyak organisasi menunjukkan bahwa pekerja yang diterima melalui jalur ini menjadi pekerja yang baik karena mereka biasanya berusaha untuk tidak mengecewakan orang yang membawa mereka ke dalam organsiasi.

2. Iklan, pemasangan iklan merupakan suatu jalur rekrutmen yang paling sering dan paling banyak digunakan. Iklan dapat dipasang diberbagai tempat dan menggunakan berbagai media, baik visual, audio, maupun bersifat audio visual.

3. Instansi pemerintah, disetiap pemerintah Negara dapat dipastikan adanya instansi yang tugas fingsionalnya mengurus ketenagakerjaan secara nasional.

4. Organisasi penempatan karyawan, salah satu perkembangan baru dalam dunia ketenagakerjaan ialah tumbuh dan beroperasinya organisasi-organisasi swasta yang kegiatan utamanya adalah mencari dan menyalurkan karyawan.

5. Organisasi pencari karyawan professional, dimana mengkhususkan diri pada karyawan tertentu saja, misalnya tenaga eksejutif atau tenaga profesioanl lainnya yang memiliki pengetahuan atau tenaga khusus. 
6. Lembaga pendidikan, sebagai sumber rekrutmen karyawan baru adalah yang menyelenggarakan pendidikan tingkat sekolah menengah, tingka atas dan pendidikan tinggi.

7. Organisasi profesi, makin maju suatu masyarakat makin banyak pula organisasi profesi yang dibentuk seperti dibidang kedokteran, teknik, hali, statistic, ahli matematika, ahli komunikasi, ahli pertanian dan lain sebagainya.

8. Serikat pekerja, banyak Negara serikat pekerja tidak hanya terbentuk di organisasi dimana semua pekerja, terlepas dari jenis pekerjaan dan jenjang pangkatnya, menjadi anggota tetapi ada serikat pekerja yang keanggotaannya didasarkan pada profesi atau bidang keterampilan.

9. Balai latihan kerja milik pemerintah, salah satu maksud dan tujuan didirikannya balai latihan adalah mengurangi tingkat pengagguran, seperti diketahui pengangguran dapat digolongkan pada dua jenis utama, yaitu pengangguran structural dan non structural (Arifin, 2017).

Prinsip-prinsip rekrutmen antara lain : 1) kualitas calon karyawan harus sesuai dengan kebutuhan yang diperlukan untuk mendapatkan kualitas yang diinginkan; 2) jumlah karyawan yang diperlukan harus sesuai dengan job yang tersedia untuk itu perlu dilakukan: permalan kebutuhan tenaga kerja, dan analisis terhadap kebutuhan tenaga kerja; 3) biaya yang diperlukan diminimalkan; 4) perencanaan dan keputusan-keputusan strategis tentang perekrutan; 5) flexibility; 6) pertimbangan-pertimbangan hukum. Sedangkan alasan yang mendorong suatu organisasi melakukan penarikan sumber daya manusia yaitu: 1) berdirinya organisasi baru; 2) adanya perluasan kegiatan organisasi; 3) terciptanya pekerjaan dan kegiatan-kegiatan baru; 4) adanya pekerja yang pindah keorganisasi lain; 5) adanya pekerja yang berhenti, baik dengan hormat maupun tidak dengan hormat sebagai tindakan preventive; 6) adanya pekerja yang berhenti karena memasuki usia pensiun; 7) adanya pekerja yang meninggal dunia (Larasati, 2018).

\section{B. Pengorganisasian Tenaga Pendidik}

Pengorganisasian adalah kegiatan mengorganisir semua karyawan melalui menetapkan pembagian kerja, hubungan kerja, pendelegasian wewenang, integrasi dan koordinasi dalam bagan organisasi (Hasibuan, 2005). Pengorganisasin merupakan kegiatan 
pengelompokan setiap wewenang atau pembagian tugas (job description) setiap guru dan staf. Sekolah harus mampu memilahmilah setiap pekerjaan sesuai dengan kapasitasi masing-masing. Seorang guru yang profesional maka harus melaksankan tugas sesuai dengan ilmu yang dimilikinya (Syahrul \& Nurmayanti, 2019). Dalam pengorganisasian ini perlu diperhatikan semua kekuatan dan sumber daya yang dimiliki, sumber daya manusia ditentukan dalam stuktur organisasi, tata dan pola kerja, prosedur dan iklim organisasi secara transparan (Ekawati, 2018).

Agar pengorganisasian tenaga pendidik dapat berjalan dengan baik hendaklah memiliki ciri-ciri atau sifat sebagai berikut: 1) memiliki tujuan yang jelas; 2) tiap anggota memahami dan menerima tujuan tersebut; 3) adanya kesatuan arah sehingga dapat menimbulkan kesatuan tindakan dan kesatuan pikiran; 4) adanya kesatuan perintah, para bawahan hanya mempunyai seorang atasan langsung dari padanya ia menerima perintah atau bimbingan dan kepada siapa ia harus mempertanggungjawabkan hasil pekerjaannya (Rosita, 2017).

Ada tiga langkah dalam pengorganisasian yaitu: 1) Pemerincian seluruh pekerjaan yang harus dilaksanakan untuk mencapai tujuan organisasi; 2) Pembagian beban pekerjaan total menjadi kegiatan-kegiatan yang logis dapat dilaksanakan oleh satu orang; 3) Pengadaan dan pengembangan suatu mekanisme untuk mengkoordinasikan pekerjaan para anggota pekerja, para anggota menjadi kesatuan yang terpadu dan harmonis (Fattah, 2004).

\section{Pengarahan Tenaga Pendidik}

Pengarahan adalah kegiatan mengarahkan semua karyawan, agar bersedia bekerja sama, bekerja efektif serta efisien dalam membantu tercapainya tujuan perusahaan, karyawan, dan masyarakat. Pada umumnya pengarahan akan dilakukan oleh atasan dengan menugaskan bawahan agar mengerjakan semua tugasnya dengan baik dan benar (Hasibuan M. S., 2005). Menurut Siagian pengarahan merupakan keseluruhan usaha untuk mendorong para anggota organisasi agar mau dan ikhlas bekerja dengan sebaik mungkin demi tercapainya tujuan organisasi dengan efisien, efektif dan ekonomis (Daryanto, 2013). Pengarahan yang dilakukan oleh kepala sekolah mempunyai fungsi membantu guru dalam mengubah rencana kedalam tindakan dan untuk meningkatkan efektifitas dan efisiensi kerja secara maksimal serta menciptkana lingkungan kerja yang sehat dan dinamis 
(Prastowo, 2014), cara-cara pengarahan yang dilakukan oleh kepala sekolah yaitu:

1. Orientasi, yaitu cara pengarahan dengan memberikan informasi yang perlu supaya kegiatan dapat dilakukan dengan baik.

2. Perintah, yaitu pengarahn dengan cara meminta kepada guru melaksanakan tugas dengan baik dengan menggunakan bahasa yang santun dan bersahabat.

\section{Pengembangan Tenaga Pendidik}

Menurut lolowang at al, pengembangan SDM adalah upaya yang dilakukan untuk membentuk personal yang berkualitas serta memiliki keterampilan, kemampuan kerja, dan loyalitas kerja terhadap perusahaan ataupun organisasi (Elbadiansyah, 2019). Singodimedjo mengemukakan pengembangan SDM adalah proses persiapan individu-individu untuk memikul tanggung jawab yang berdea atau lebih tinggi di dalam organisasi, biasanya berkaitan dengan peningkatan kemampuan intelektual untuk melaksanakan pekerjaan yang lebih baik (Sutrisno, 2009).

Berbagai aktivitas yang dapat dilakukan oleh suatu organisasi dalam usaha pengembangan tenaga kerja, antara lain:

1. Pelatihan atau pendidikan

Dengan latihan atau pendidikan diartikan sebagai kegiatan organisasi yang didesain untuk memperbaiki atau meningkatkan pengetahuan, keterampilan, dan mengubah sikap pegawai sesuai dengan kebutuhan organisasi sehingga yang bersangkutan lebih maju dalam melaksanakan tugas tertentu, latihan lebih bersifat praktris sedangkan pendidikan lebih bersifat reoritis.

2. Rotasi jabatan

Dengan rotasi jabatan seorang karyawan ditugaskan memegang jabatan yang berbeda dari satu waktu ke waktu yang lain. Selain agar karyawan memahami pelaksanaan berbagi tugas, juga agar ia memperolah pengetahuan yang lebih luas mengenai berbagai jabatan. Dalam penerapan rotasi jabatan perlu diperhatikan hal-hal sebagai berikut: 1) Jabatan karyawan yang dipindahkan harus bersamaan isisnya dengan jabatan yang ditinggalkan, 2) metode melakukan pekerjaan harus sama antara yang satu dengan yang lain, 3) pejabat yang dimutasikan harus mempunyai 
pengalaman yang memungkinkan mengerti dasar-dasar pekerjaan baru.

3. Delegasi

Manajemen adalah mencapai hasil melalui orang lain, karenanya untuk dapat merealisir itu, delegasi pleh manajer mutlak perlu. Salah satu kualifikasi penting dari seorang manajer adalah kesanggupan mendelegasikan sebagaian tugas dan wewewnangnya kepada bawahannya. Dalam pelaksanaannya agar delegasi itu dapat efektif sebaiknya diperhatikan hal-hal sebagai berikut: 1) unsure-unsur delegasi harus lengkap dan jelas, 2) delegasi diberikan kepada orang yang tepat, 3) delegasi harus dibarengi dengan peralatan, waktu , biaya yang diperlukan, 4) kepada mereka yang menerima delegasi harus dimotivasi dengan member intensif yang diperlukan.

4. Promosi

Promosi adalah kegiatan pemindahan karyawan dari satu jabatan ke jabatan lain yang lebih tinggi, dimana tugas, wewenang, tanggung jawab lebih tinggi dari sebelumnya. Salah satu sasaran tindakan promosi ialah untuk mengembangkan pegawai, sebab pegawai yang cukup berprestasi pada jabatannya harus dikembangkan dengan menugaskan ia untuk menerima tugas, wewenang dan tanggung jawab yang lebih besar dari sebelumnya.

5. Pemindahan

Pemindahan atau transfer adalah kegiatan mengganti jabatan karyawan yang setingkat. Dalma hal ini, sekelompok kerja, tempat kerja, atau kesatuan organisasi pegawai diubah dengan tujuan perhatian dan kemampuan kerjasama dapa meningkat. Dari segi tujuan, pemindahan dibedakan atas lima macam, yaitu production transfer, replacement transfer, versality transfer, shift transfer, dan remedial transfer.

6. Penugasan dalam keanggotaan suatu panitia

Menugaskan seorang karyawan sebagai salah seorang anggota suatu panitia dapat digunakan sebagai suatu cara dalam pengembangan pegawai. Setiap anggota panitia akan bekerjasama dengan anggota paniti lainnya melaksanakan satu atau beberapa tugas dan bersama-sama bertanggung jawab akan pelaksanaan tugas tersebut sebaik-baiknya. Dalam 
penugasan seorang karyawan menjadi anggota suatu panitia, maka dia dapat mengembangkan dirinya dalam hal menghargai orang lain, cara berapat, cara mengambil keputusan dalam rapat, bekerjasama dengan orang lain dan menambag pengetahuan berbagai seginya (AlMasri, 2016).

\section{E. Pemberhentian Tenaga Pendidik}

Pemberhentian merupakan proses pemutusan hubungan kerja seseorang karyawan dengan suatu organisasi. Dengan pemberhentian ini berakhirnya keterikatan kerja antara karyawan tersebut dengan pihak organisasi, banyak alasan yang menyebabkan terjadinya proses pemberhentian karyawan, diantaranya adalah : keinginan organisasi, keinginan karyawan, karena kontrak kerja yang sudah habis, pension, kesehatan, perusahaan dilikuidasi atau juga karena meninggal (Sofyandi, 2008).

Pemberhentian oleh dinas atau pemerintah dapat dilakukan dengan beberapa alasan sebagai berikut: 1) pegawai yang bersangkutan tidak cakap dan tidak memiliki kemampuan untuk melaksanakan tugas-tugasnya dengan baik, 2) perampingan atau penyederhanaan organisasi, 3) peremajaan, biasanya pegawai yang telah berusia 60 tahun dan berhak pension harus diberhentikan dalam jangka waktu satu tahun, 4) tidak sehat jasmani dan rohani sehingga tidak dapat melaksankaan tugasnya dengan baik, 5) melakukan pelanggaran tindak pidana sehingga dihukum oenjara atau kurungan, dan 6) melanggar sumpah atau janji pegawai negeri sipil (Bachtiar, 2016).

\section{Kesimpulan dan Implikasi}

Perencanaan yang dilakukan melalui analisis faktor kebutuhan sumber daya pendidik kemudian menentukan kebutuhan sumber daya pendidik, perencanaan juga dilakukan pada rapat awal tahun di mana didalamnya membahas hal-hal yang perlu dibenahi di TPQ yaitu materi pembelajaran, sarana dan prasarana dan ujian santri. Pengorganisasian dengan membagi setiap tenaga pendidik untuk bertanggungjawan terhadap level/kelas masing-masing sesuai dengan kualitas yang dimiliki dan memberikan tugas tambahan kepada guru untuk menduduki jabatan sebagai sekertaris dan bendahara. Pengarahan yang dilakukan oleh pimpinan mengacu pada dua aspek yaitu kedisiplinan dan tanggungjawab tenaga pendidik. Rekrutmen 
dilakukan untuk mendapatkan tenaga pendidik yang sesuai dengan yang dibutuhkan melalui penugasan kepada masing-masing guru untuk mencari guru yang sesuai dengan kriteria dan persyaratan yang telah di tentukan oleh pihak TPQ. Pengembangan dilakukan melalui rotasi jabatan dan peembelajaran secara berkelompok yang melibatkan semua guru-guru TPQ. Pemberhentian tenaga pendidik di dasari oleh kemauan dari guru itu sendiri dengan faktor yang berbeda-beda..

Oleh karena itu, lembaga pendidikan nonformal seperti Taman Pendidikan Al-Qur'an mesti membenahi tata kelola, tidak melakukan pengelolaan yang bersifat rutin saja, tetapi melangkah lebih maju dengan adaptasi teknologi, terutama dalam pembuatan sistem informasi SDM. Selain itu, penetapan tujuan dan pembuatan kebijakan mesti dikategorisasi dalam tujuan dan kebijakan jangka pendek, menengah, dan panjang. Pengembangan SDM mesti dilakukan secara gradual tetapi terarah. Evaluasi rencana dan program tidak hanya bersifat teoritik-formalistik, tetapi lebih dari itu adalah menghasilkan perencanaan dan pemrograman ulang (replanning and reprogramming) yang lebih sesuai semangat zaman.

\section{Daftar Pustaka}

Akilah, F. (2017). Manajemen Perencanaan Sumber Daya Manusia di Bidang Pendidikan: Manifestasi dan Implementasi. Jurnal Kependidikan, Vol. 11 No. 1 Juni, 81-94.

Almasri, M. N. (2016). Manajemen Sumber Daya Manusia: Implementasi dalam Pendidikan Islam. Jurnal Penelitian

Sosial Keagamaan, Vol. 19, No. 2 Juli-Desember.

Aminullah, A. (2017). Pengaruh Penerapan Manajemen Mutu Terhadap Kualitas Sumberdaya Pendidik TPQ Darussalam Blokagung Tegalsari Banyuwangi Tahun Pelajaran 2017. Jurnal Darussalam: Jurnal Pendidikan, Komunikasi dan Pemikiran Hukum Islam, 9(1), 50-65.

Arifin, N. (2017). Manajemen Sumber Daya Manusia : Teori dan Kasus. Jepara: UNISNU PRESS.

Azis, D. K. (2015). Profesionalisme Guru TPQ Baitul Jannah. JPA, Vol. 16 No. 1 Januari-Juni, 17.

Bachri, B. S. (2010). Meyakinkan Validitas Data Melalui Traingulasi pada Penelitian Kualitatif. Jurnal Teknologi Pendidikan Vol. 10, No. 1 , 46-62. 
Bachtiar. (2016). Pendidik dan Tenaga Kependidikan. Publikasi Pendidikan.

Badrudin. (2013). Dasar-Dasar Manajemen. Bandung: Alfabeta.

Barthos, B. (2012). Manajemen Sumber Daya Manusia (Suatu Pendekatan Makro). Jakarta: Bumi Aksara.

Creswell, J. W. (2014). Penelitian Kualitatif dan Desain Riset: Memilih di antara Lima Pendekatan. Yogyakarta: Pustaka Pelajar.

Daryanto. (2013). Administrasi dan Manajemen Sekolah. Jakarta: Rineka Cipta.

Dewi, F. P. (2019). Manajemen Sumber Daya Pendidik dan Tenaga Kependidikan di SD Kristen Kalam Kudus Surakarta. SKRIPSI, Universitas Muhammadiyah Surakarta, 4.

Ekawati, F. (2018). Manajemen Sumber Daya Manusia dalam Meningkatkan Mutu Pendidikan di SMPIT. Jurnal Islamic Education Manajemen, Vol. 3, No. 2 Desember.

Elbadiansyah. (2019). Manajemen Sumber Daya Manusia. Malang: CV IRDH.

Faisal, S. (2001). Metode Penelitian Sosial. Jakarta: Erlangga.

Farikhin, F. (2018). Manajemen Sumber Daya Pendidik Dalam Pembelajaran Al-Qur'an (Studi Kasus di Taman Pendidikan Al-Qur'an Yasinat Jember). Jurnal Pendidikan, Sosial dan Keagamaan, 184-225.

Fattah, N. (2013). Landasan Manajemen Pendidikan. Bandung: PT Remaja Rosdakarya.

Gunawan, I. (2014). Metode Penelitian Kualitatif Teori dan Praktek. Jakarta: Bumi Aksara.

Hadijaya, Y. (2012). Administrasi Pendidikan. Medan: Perdana Publishing.

Hamalik, O. (2001). Pendidikan Guru: Konsep dan Strategi. Bandung: CV Mandar Maju.

Handoko, T. H. (2012). Manajemen. Yogyakarta: Grafindo.

Harahap, A. (2019). Manajemen Tenaga Pendidik di MTs Darul Falah Langgapayun Kabupaten Labhan Batu Selatan. Jurnal Ecobisma, Vol. 6 No. 1 Januari, 33.

Hasibuan, M. S. (2011). Manajemen Sumber Daya Manusia. Jakarta: Bumi Aksara. 
Huda, H. (2018). Optimalisasi Manajemen Sumber Daya Pendidik (Ustad) Pondok Pesantren Miftahul Ulum Suren Ledokombo Jember. Jurnal All-Ta'dib Vol. 11, No. 1 Januari-Juni, 1.

Imam, G. (2013). Metode Penelitian Kualitatif. Jakarta: Bumi Aksara. Kadarisma, M. (2013). Manajemen Pengembangan Sumber Daya Manusia. Jakarta: Rajawali Pers.

Karno, E., \& Syahrul. (2020). Management of Educators in Private Schools in Indonesia. International Journal of Advance Research and Innovative Ideas in Education, 6(4), 608-612.

Kemenag, S. (2007). Retrieved from htttp://sultra.kemenag.go.id/file/dokumen.PP.NO.55.Tahun.20 07.pdf.hlm.10

Kusuma, Y. (2018). Model-Model Perkembangan Pembelajaran BTQ di TPQ/TPQ di Indonesia. J-PAI Vol. 5 No. 1 Juli-Desember.

Larasati, S. (2018). Manajemen Sumber Daya Manusia. Yogyakarta: CV Budi Utama.

M. Rusni Eka Putra, d. (2018). Manajemen Tenaga Pendidik SDIT Mutiara Cendekia Lubuklinggu. Journal of Administration and Educational Management (ALIGMENT) Vol. 1 No. 1 Juni, 4142.

Malik, H. A. (2013). Pemberdayaan Pendidikan Al-Qur'an (TPQ) Alhusna Pasadena Semarang. Dimas Vol. 13 No. 2 , 388.

Maujud, F. (2018). Implementasi Fungsi-Fungsi Manajemen dalam Lembaga Pendidikan Idlam (Studi kasus peneglolaan Madrasah Ibtidaiyah Muta'allim Pagutan). Jurnal Penelitian Keislaman, Vol. 14 No. 1.

Miles, M. B., Huberman, A. M., \& Saldana, J. (2013). Qualitative data analysis. Jakarta: UI Press.

Moleong, L. J. (2006). Metode Penelitian Kualitatif, Edisi Revisi. Bandung: Remaja Rosdakarya.

Muflihin, M. H. (2016). Manajemen Disiplin Kerja: Perspektif Tenaga Pendidik dan Kependidikan. LENTERA PENDIDIKAN, Vol. 19 No. 1 Juni.

Munawaroh, I. M. (2014). Manajemen Pengembangan Sumber Daya Pendidik di Taman Pendidikan Al-Qur'an (TPQ) Al-Hidayah Purwogondo Kalinyamatan Jepara. Jurnal An Nur, Vol. VI No. 2 Desember, 203-225.

Muniroh, J. (2017). Manajemen Pendidik dan Tenaga Kependidikan di Madrasah Aliyah Negeri Kota Yogyakarta. Jurnal 
Akuntabilitas Manjemen Pendidikan Vol. 5 No. 2 September, 161.

Noor, M. (2019). Manajemen Sumber Daya Pendidik di Madrasah Aliyah Al Hikmah 1 Benda Sirampong Brebes. Tesis, IAIN Purwokerto, 71.

Novia N Anwari, d. (2019). Pengorganisasian Tenaga di Usaha Kovensi Adiguna Bordie Kota Bengkulu. Journal of Lifelong Learning Vol. 2 No. 2 70-74 Desember, 2.

Nurohmawati, F. (2017). Manajemen Sumber Daya Manusia di MTs Se Kecamatan Kroya Kabupaten Cilacap. SKRIPSI, IAIN Purwokerto, 1.

Prastowo, H. (2014). Pengelolaan Tenaga Pendidik di Sekolah Dasar Negeri 1 Ringin Larik Boyolali. Skripsi, Universitas Muhammadiyah Surakarta, 10.

Rajaloa, N. I., \& Hasim, R. (2016). Manajemen Perencanaan dan Rekrutmen Tenaga Pendidik Oleh Dinas Pendidikan Kota Ternate. EDUKASI-Jurnal Pendidikan Vol. 16 No.1 Januari, 11-28.

Rosita, D. (2017). Manajemen Tenaga Pendidik dan Kependidikan di Jurusan Kebidanan Polteknik Kesehatan Kementerian Kesehatan Pontianak. Skripsi, Universitas Tanjungpura, 8.

Rustam Hasim, N. I. (2017). Manajemen Sumberdaya Manusia Tenaga Pendidik Oleh Dinas Pendidikan Kota Ternate. Jurnal Penelitian Humano, Vol. 8 No. 2 Edisi November, 126.

S, U. (2014). Manajemen Ekstrakurikuler dalam Meningkatkan Mutu Sekolah. Al Fikrah: Jurnal Kependidikan Islam Vol. V, No. 1.

Saichu, K. F. (2018). Pemberdayaan Taman Pendidikan Al-Qur'an (TPQ) melalui penguatan SDM di Masjid Nurul Fikri Watu Bonana, Badegan, Ponorogo. Qalamuna, Vol. 10 No. 2 JuliDesember.

Samsirin. (2015). Konsep Manajemen Pengawasan dalam Pendidikan Islam. Jurnal At-Ta'dib, Vol. 10, No. 2 Desember.

Sanjani, M. A. (2018). Peningkatan Manajemen Sumber Daya Tenaga Pendidik. Jurnal Serunai Administrasi Pendidikan Vol. 6 No. 2 Juni, 18.

Sari, N. Y. (2018). Pentingnya Etika dan Profesionalsme Pendidik dalam Perkembangan Moral Peserta Didik. Jurnal Studi Islam dan Sosial, Vol. 11, No.2. 
Sarwono, J. (2006). Metode Penelitian Kuantitatif dan Kualitatif. Yogyakarta: Graha Ilmu.

Sofyandi, H. (2008). Manajemen Sumber Daya Manusia. Yogyakarta: Graha Ilmu.

Stoner, J. A. (1996). Manajemen. Jakarta: PT. Prenhallindo.

Sugiyono. (2013). Memahami Penelitian Kuantitatif, Kualitatif \& RD. Bandung: Alfabeta.

Suparno, W. (2015). Manajemen Pengembangan Sumber Daya Manusia. Yogyakarta: PUSTAKA PELAJAR.

Susan, E. (2019). Manajemen Sumber Daya Manusia. Jurnal Manajemen Pendidikan Islam Vol. 9 No. 2 Agustus, 954-955.

Sutrisno, E. (2009). Manajemen Sumber Daya Manusia. Jakarta: Kencana.

Suwatno, d. (2011). Manajemen Sumber Daya Manusia. Bandung: Alfabeta.

Syaharuddin, d. (2018). Peningkatan Manajemen Tata Kelola dan Metode Baca Tulis Al-Qur'an Guru dan Santri Kelompok TPQ di Lombok Tengah NTB. Jurnal Pemberdayaan Masyarakat Berkarakter, Vol. 1 No. 1 Agustus, 11.

Syahrul, \& Nurmayanti. (2019). Pengelolaan Pendidik dan Tenaga Kependidikan di SMA Muhammadiyah Kendari. Shautut Tarbiyah Volume 25, Nomor 2, 267-268.

Triwiyanto, N. U. (2016). Manajemen Sumber Daya Manusia Bidang Pendidikan. Jakarta: Raja Grafindo Persada.

Upe, A. (2012). Manajemen Taman Pendidikan Al-Qur'an (TPQ) di Kecamatan Tembilahan Kabupaten Indragiri Hilir. Tesis, UIN Sultan Syarif Kasim Riau, 20.

Usman, M. U. (2002). Menjadi Guru Profesional. Bandung: Remaja Rosda Karya.

Waidiansyah, A. (2018). Peranan Sumber Daya Pendidikan sebagai Faktor Penentu dalam Manajemen Sistem Pendidikan. Jurnal Humaniora, Vol. 18 No. 2 September, 229.

Yacoeb. (2013). Konsep Manajemen dalam Perspektif Al-Qur'an: Suatu analisis dalam bidang administrasi pendidikan. Jurnal Ilmiah DIDAKTIKA, Vol XIV, No. 01 Agustus.

Yasaratodo. (2008). Upaya Optimalisasi Kinerja Tenaga Edukatif di Perguruan Tinggi. Jurnal Tabularasa PPS Unimed, Vol. 5 No. 1 Juni. 